\title{
Potential Benefits of Russian Northern Sea Route in Global Supply Chain
}

\author{
Vladimir A. Lazarev \\ ${ }^{(1)}$ Department of Management, ${ }^{(2)}$ Primorsky Laboratory \\ ${ }^{(1)}$ Russian Customs Academy, Vladivostok Division, \\ ${ }^{(2)}$ Economic Research Institute, Far-Eastern Branch of the \\ Russian Academy of Sciences \\ Vladivostok, Russia \\ vlad.lazarev@list.ru
}

\author{
Andrey I. Fisenko \\ Department of Economics and Finances \\ Maritime State University named after G.I. Nevelskoy \\ Vladivostok, Russia \\ fisenko@msun.ru
}

\begin{abstract}
The article represents the authors' outlook on the logistics issue of Northeast China. Excessive expenses on logistics make it difficult to organize well-planned transportation of commodity goods from Northeast China to the world markets. Consequently, the drawback in social and economic development of Northeast China creates demographic tension on the border between China and Russia. The logistics expenses could be whittled down with the help of new logistics network, i.e. the seaports of the South of Primorsky region like Posyet or Zarubino. Additionally, in the summer period the commodity goods may be shipped to Europe through the Northern Sea Route. Northern Sea Route is an option that may significantly reduce the logistics expenses and allow raising the prosperity of the Northeast China. Economic benefits of the Northern Sea Route are considered in the article. Finally, the authors present the concept of logistic burden and adjusted logistic burden allowing one to calculate the financial benefit from utilizing faster logistics route for commodity flow of goods.
\end{abstract}

Keywords - logistics, demographic tension, Northeast China, Arctic regions, Northern Sea Route, logistics burden.

\section{INTRODUCTION}

Nowadays the intensive development and strengthening of the processes that attract the attention of national economies to the most effective transport routes are observed. The cumulative process of industrial agglomeration and transformation is obvious in Asia and especially in China, where it results in development of clustering concentration. Obviously, the effect of economies of scale in China has exceeded the critical level that has initiated a self-accelerating endogenous process of concentration of production and financial sectors of the national economy. Over one and a half billion of consumers in China and another three billion of consumers in the neighboring area, including South East Asia and India, comprise the material base aimed at minimization of transportation costs for industrial manufacturers. The growing variety of manufactured goods provides the third important component of concentration - the elastic demand in conditions of imperfect competition. Simultaneously, to the west of Russia, one may see the parallel process of withdrawal of the production sector from the economies of the European Union and transformation of economics to the service or postindustrial format. In the past, the similar global process could split the regions into the well-developed industrial centre and underdeveloped provinces. However, in the modern world of the industrial-postindustrial economic structure, the multiplication of resulting trends transforms the Asian industrial centre into the core of the world industrial production while the developed countries, including the European Union - into the centre of intellectual labor.

\section{FEASIBILITY STUDY}

The population of the Northeast China creates the excessive demographic tension in the neighboring countries, mostly in Russia. The total population of Heilongjiang, Jilin and Nei Mongol (Inner Mongolia) provinces, bordering Russia, exceeds 90 million people (estimation of 2010). The average population concentration in this region of China reaches 50 people per square kilometer. Excluding relatively low-populated Nei Mongol, the population concentration in the region exceeds 105 people per square kilometer. On the other side of the Russian-Chinese border, there is the underpopulated Russian Far East with the average population concentration as low as 1 person per square kilometer. In the most populated region of the Russian Far East, Primorsky Region, the population concentration hardly amounts to 11 people per square kilometer. Great difference in the population concentration affects the mutual relations of the neighboring countries [1]. Over the last 150 years of Russia and China neighboring, there were at least three frontier military conflicts where the demographical gap was the ground zero. In this regard, according to the authors, Russia is interested in the growth of economic prosperity of China because this is the most important subcomponent reducing the negative potential of demography tension.

Compared to other provinces, first of all Central and Southern, the Northeast China may be fairly called the moderately depressive regions. Despite quite high economic indicators, for example, GDP per capita in the Nei Mongol amounted to USD 11,500 in 2015 , the number of people looking for a job or unsatisfied with their job in the Northeast China may be estimated at 8-10 million men, or equivalent to $12 \%$ of population [2], while the official level stated was $5 \%$. 
Thus, it may be assumed that one of the basic constraints of development of the Northeast China is the excessive logistics costs that are caused by the resistance to initiate there logistics chains supporting the shipping of commodities produced in the region. The excessive resistance to the seamless action of the logistics chains entails some extra expenditures during the transportation in terms of time and money. The main reason of the current situation is the absence of the direct approach to large transport hubs of the global logistics network by the Northeast China. The basic linkage of commodity traffic from the Northeast China is automotive or railway route to the port of the Yellow Sea and then by sea through the Suez Channel to Europe, or through the Pacific Ocean to America. This route forms the essential time-domain and financial costs for surface cut because both the highways and the railways in China are heavily loaded. For example from the authors' personal experience, the 500-kilometer trip of the cargo train from the city of Harbin to the Russian border took three days in 2008. And though the high-speed railways have been constructed in China, they may be used for transportation of passengers only.

Today China tries to solve a problem of logistics availability of industrial facilities of the Northeast China all alone; among other developing global projects, it is known as the New Silk Road [3, 4]. However, it seems that this project is progressing too slowly because of the significant number of stakeholders with opposite intentions. First of all, China is interested to make this route fast and cheap. The countries on the New Silk Road, vice versa, are awaiting significant benefits from allowing a passage to Chinese commodity flow through their national territory.

From the 90-s of the XX century, the Chinese government has been undertaking series of efforts to get the access to the seaports of South Primorye, preferably to the seaport Zarubino, or officially, the Sea Port in Troitsa Bay. Port Posyet is also a point of interest. Both ports are able to accommodate the ships with the gross registered tonnage of up to 20,000 tons [5].

Also, it is worth mentioning the Tumen River Area Development Program in its few different versions aimed at the development of the Tumen river area that potentially gives China the direct access to the Japan Sea. After 2006, the Program was renamed to the Greater Tumen Initiative. Several projects are developed in the framework of this program, including the ambitious shipping channel from Hunchun to Expedition Bay of the Japan Sea.

\section{RUSSIAN LOGISTICS OFFER IN THE NORTHERN EAST CHINA}

The Russian Federation is the owner of two large resources allowing fast shipping of commodity from Asia to Europe, the Trans-Siberian Railway and the Northern Sea Route. The transit offer of the Trans-Siberian Railway is quite low because its potential capacity is almost exhausted [6, 7]. At the same time, the Arctic region attracts the attention of global economies. The water area of the Arctic Ocean arouses the increasing interest of the adjoining countries, as well as of the countries which economic wealth strongly depends on the external resources, including potential resources of the Arctic regions, and low-cost ways of commodity transportation. Huge reservoirs of natural resources in the Arctic regions and obvious advantages of the routes in the Arctic seas entail the increasing interest in the Arctic regions of leading world economies. Right now, the dominating tendency in geostrategies of the USA, Canada, Denmark, Norway, Iceland, and Russia is the development of national programs and doctrines proving the sole rights for economic activities in their sectors of Arctic [8, 9]. Recently Canada adopted the decision about the termination of commercial operation in their northern route, the North-Western Passage, till 2020. That means that Canada will prevent any attempts of other countries to organise any economic activity in the zone of national interest. To fasten and expand the special privileges in the Arctic regions, the leading states try to use their influence on legislative machines of international organizations. Under new conditions, the non-arctic states are looking for loopholes in the international legislation and are using their financial and economic influence to infiltrate the giant potential market of the hydrocarbons extraction in the Arctic continental shelf and their transportation. China and South Korea with their particular interest in the Arctic regions show the greatest concern.

China has purchased the bulk carrier of the first ice class from Kherson Shipyard, Ukraine in 1993. The ship was named Xuelong that means the snow dragon; and it is usually referred to as an icebreaker in official Chinese press. China has been conducting the research activity in the Arctic regions on a regular basis since 1994. In 2009, the State Council of the Peoples' Republic of China has accepted the program of building the national icebreaking fleet. The first Chinese civil icebreaker was planned to be ready in 2013; however, it seems that the Jiangnan Shipyard Company has started its building only at the end of 2016. The Chinese national army has its own icebreakers. At the end of 2015, in Huludao, Liaoning province, the diesel powered icebreaker Haibing 722 was transferred to the Northern Fleet of Naval Forces of China Peoples Liberation Army. Another analogous icebreaker is now under the final processing in the shipyard of Bohai Shipbuilding Heavy Industry Company, Ltd [10]. The Republic of Korea builds its icebreakers too. The first Korean icebreaker named Araon with gross registered tonnage of 6,950 tons was constructed in the Republic of Korea and was placed in operation in 2009. Now Aaron conducts research in the Arctic and Antarctic. Japan with its large export-focused economy is aimed mostly at trading with the North America; therefore, its participation in the processes in the Arctic is not very obvious.

The logistics chain connecting the Northeast China with the European countries may utilize the following great promising route:

- commodity flow to the port of the South Primorye, to the Posyet port or to the Sea Port in Troitsa Bay;

- during the summer period, the shipping line extends from the port of the South Primorye to the North of the Western hub of the Northern Sea Route, presumably Murmansk, and then turns to transportation by land to Europe; 
- during the winter period, the shipping line extends from the port of the South Primorye to the South of any port in Europe through the Suez Channel.

Even in the winter period, the logistics chain through the port of the South Primorye may give significant benefits to the business in the Northeast China. These benefits will grow more in the summer time when the Northern Sea Route is open for general shipping.

\section{ECONOMIC EFFICIENCY OF THE NORTH SEA ROUTE}

According to data [11], the commodities being produced in the Asian industrial centre and being sold in the developed economies show the growth of the final price by:

- $20 \%$ due to the transportation expenses;

- $45 \%$ due to transfrontier costs;

- $55 \%$ due to retailing costs.

The total growth of the consumer price amounts to as high as $170 \%$ of the manufacturer price. These expenses are contraproductive because they do not improve the value of goods. Any savings in contra-productive expenses will provide the competitive advantage for a beneficial owner. From the point of the introduction of the Northern Sea Route into the global logistics system, the advantage of the new route for commodity owners appears to be the most important factor.

At present, the cargoes from Asia to Europe are shipped mostly through the Indian Ocean and the Suez Channel. For Northeast China, the selected alternative to the Northern Sea Route is the Dalian-Hamburg route through the Suez Channel.

The distance from Dalian to Hamburg by sea is 11,200 nautical miles while the sea route from Posyet to Murmansk barely achieves 6,000 nautical miles, or almost twice shorter. Experience shows that the Dalian-Hamburg route by sea takes from 35 to 45 days and costs about USD 1,500-1,700 per twenty-foot container unit, including:

- USD 200 sea toll;

- USD 800 bunker adjustment factor;

- USD 50 Suez Channel toll;

- the rest of the tariff covers the currency adjustment factor, freight operations, terminal handling charges, security charges, agent charges, peak season surcharges, heavy load surcharges, etc.

Additional charge of USD 100 per container or up to USD 60,000 per ship is applied due to piracy activity in the Aden Gulf. Usually it appears in documents as the Aden Gulf Security Adjustment. The exact amount of the insurance premium depends on the insurance company policy.

Because of a shorter distance from Posyet to Murmansk thus omitting the Suez Channel toll, one may suppose that the coast of shipping would be about USD 750-800 per twentyfoot unit on this route and $20-25$ days in transit.

However, there is another difficulty on the way. The Northern Sea Route is very dangerous due to unpredictable ice conditions. A ship on the Northern Sea Route may face the ice blocks and ice fields even during the summer season. Continuous danger of the Northern Sea Route has formed special requirements for the navigation in polar waters. The heaviest burden is the requirement of icebreaker convoying.

In the Soviet era, the Northern Sea Route was a very important way to supply Arctic regions of the Soviet Union and the intensity of shipping through it was very high [12]. At the end of the Soviet era, in the middle of the 1980s, the amount of transit cargos was over 6 million tons per year, and there was a special budget supporting the transit. After the state support was exhausted, the transit amount had fallen drastically. There was a period in the beginning of 2000 when Russian government stated the prohibitive measures intended to hold the transit cargoes in the Russian Arctic. The Regulation [13], effective from 2005, and the one adopted later [14], which has been effective since 2011, have established the maximum permissible toll for an icebreaker convoy. The tariffs for cargo ships convoying were the same in 2005 and 2011 despite the inflation. The extracts from both Regulations are given in Table I.

TABLE I. THE MAXIMUM PERMISSIBLE TOLL FOR ICE-BREAKER CONVOY IN THE NORTH SEA ROUTE

\begin{tabular}{|l|l|l|}
\hline \multicolumn{1}{|c|}{ Type of cargo } & $\begin{array}{c}\text { Tariff, RUR } \\
\text { per ton (2005) }\end{array}$ & \multicolumn{1}{c|}{$\begin{array}{c}\text { Tariff, RUR per } \\
\text { ton (2011) }\end{array}$} \\
\hline Standard container unit & 1048 & 1048 \\
\hline Base (nonferrous) metal & 2050 & 2050 \\
\hline Machinery and equipment & 2464 & 2464 \\
\hline Bulk cargo & 707 & 707 \\
\hline Tanker cargo & 530 & 530 \\
\hline
\end{tabular}

At that time, the cost of icebreaker convoying was adding about USD 500 to the total transportation expenses per twenty-foot unit (for homogenous commodity weighing 14.4 tons in TEU and the RUB/USD exchange rate of 30/1) and made the Northern Sea Route doubtfully competitive. In fact, the cost of convoying was overvalued in early Regulations. It was even higher than an hour rate of such icebreaker as Admiral Makarov (Far Eastern Shipping Company) for port operations that ranged from USD 3,500 to USD 4,500.

After 2013, the position of the Russian government in relation to the Northern Sea Route has changed significantly. New Regulation [15] has established the new tariffs effective since 2014; the extract from it is given in Tables II and III.

These tariffs set the cost of convoy by nuclear icebreakers belonging to Federal (State) Enterprise Atomflot. New tariffs show the normal logistics approach: the bigger the ship, the cheaper the unit transportation. The total cost of convoying now depends on the distance measured in zones. Limits of the zones for general purposes, including calculations of the icebreaker convoying, are shown in Table IV.

For clear understanding of Tables II and III, the correspondence must be quoted between the ship of ice classes in Russian Maritime Register of Shipping (RMRS) and the most common ice classes. Table $\mathrm{V}$ shows the specific ice 
conditions for each class mentioned in Tables II, III [16]. Table VI shows the correspondence between the RMRS ice class and other classifications, like Baltic Ice Classes (BIC), Det Norske Veritas Classes (DNVC), Lloyd Register Ice Classes (LRIC) and the International Association of Classification of Societies Polar Classes (IACS-PC). The correspondence shown in Table VI is based on documents [17, $18,19]$ and research [20].

TABLE II. TARIFFS FOR ICE-BREAKER CONVOY OF 10,001-20,000 GROSS REGISTERED TONNAGE SHIPS, IN RUB PER 1 TON OF TONNAGE

\begin{tabular}{|l|c|c|c|c|c|c|c|}
\hline $\begin{array}{c}\text { Ship ice } \\
\text { class }\end{array}$ & $\begin{array}{c}\mathbf{1} \\
\text { zone }\end{array}$ & $\begin{array}{c}\mathbf{2} \\
\text { zones }\end{array}$ & $\begin{array}{c}\mathbf{3} \\
\text { zones }\end{array}$ & $\begin{array}{c}\mathbf{4} \\
\text { zones }\end{array}$ & $\begin{array}{c}\mathbf{5} \\
\text { zones }\end{array}$ & $\begin{array}{c}\mathbf{6} \\
\text { zones }\end{array}$ & $\begin{array}{c}7 \\
\text { zones }\end{array}$ \\
\hline No & 714.95 & 857.94 & 1000.93 & 1143.92 & 1286.91 & 1429.90 & 1429.90 \\
\hline Ice 1 & 500.46 & 600.56 & 700.65 & 800.74 & 900.83 & 1000.93 & 1000.93 \\
\hline Ice 2 & 464.72 & 557.66 & 650.60 & 743.55 & 836.49 & 929.43 & 929.43 \\
\hline Ice 3 & 428.97 & 514.76 & 600.56 & 686.35 & 772.14 & 857.94 & 857.94 \\
\hline Arc 4 & 357.47 & 428.97 & 500.46 & 571.96 & 643.45 & 714.95 & 714.95 \\
\hline Arc 5 & 353.90 & 424.68 & 495.46 & 566.24 & 637.02 & 707.80 & 707.80 \\
\hline $\begin{array}{l}\text { Arc 6 } \\
\text { Arc 9 }\end{array}$ & 350.32 & 420.39 & 490.45 & 560.52 & 630.58 & 700.65 & 700.65 \\
\hline
\end{tabular}

TABLE III. TARIFFS FOR ICE-BREAKER CONVOY OF 20,001-40,000 GROSS REGISTERED TONNAGE SHIPS, IN RUB PER 1 TON OF TONNAGE

\begin{tabular}{|l|c|c|c|c|c|c|c|}
\hline $\begin{array}{c}\text { Ship ice } \\
\text { class }\end{array}$ & $\begin{array}{c}\mathbf{1} \\
\text { zone }\end{array}$ & $\begin{array}{c}\mathbf{2} \\
\text { zones }\end{array}$ & $\begin{array}{c}\mathbf{3} \\
\text { zones }\end{array}$ & $\begin{array}{c}\mathbf{4} \\
\text { zones }\end{array}$ & $\begin{array}{c}\mathbf{5} \\
\text { zones }\end{array}$ & $\begin{array}{c}\mathbf{6} \\
\text { zones }\end{array}$ & $\begin{array}{c}\mathbf{7} \\
\text { zones }\end{array}$ \\
\hline No & 536.21 & 643.45 & 750.70 & 857.94 & 965.18 & 1072.42 & 1072.42 \\
\hline Ice 1 & 375.35 & 450.42 & 525.49 & 600.56 & 675.63 & 750.70 & 750.70 \\
\hline Ice 2 & 348.54 & 418.24 & 487.95 & 557.66 & 627.37 & 697.07 & 697.07 \\
\hline Ice 3 & 321.73 & 386.07 & 450.42 & 514.76 & 579.11 & 643.45 & 643.45 \\
\hline Arc 4 & 268.11 & 321.73 & 375.35 & 428.97 & 482.59 & 536.21 & 536.21 \\
\hline Arc 5 & 265.42 & 318.51 & 371.59 & 424.68 & 477.76 & 530.85 & 530.85 \\
\hline $\begin{array}{l}\text { Arc 6 } \\
\text { Arc 9 }\end{array}$ & 262.74 & 315.29 & 367.84 & 420.39 & 472.94 & 525.49 & 525.49 \\
\hline
\end{tabular}

TABLE IV. GEOGRAPHICAL LIMITS OF ZONES IN RUSSIAN ARCTIC

\begin{tabular}{|l|l|l|}
\hline \multicolumn{1}{|c|}{ Zone number } & East limit & \multicolumn{1}{c|}{ West limit } \\
\hline 1 (Kara Sea South-West) & $68^{\circ} 35^{\prime} \mathrm{E}$ & $79^{\circ} 00^{\prime} \mathrm{E}$ \\
\hline 2 & $79^{\circ} 00^{\prime} \mathrm{E}$ & $105^{\circ} 00^{\prime} \mathrm{E}$ \\
\hline 3 & $105^{\circ} 00^{\prime} \mathrm{E}$ & $125^{\circ} 00^{\circ} \mathrm{E}$ \\
\hline 4 & $125^{\circ} 00^{\prime} \mathrm{E}$ & $140^{\circ} 00^{\prime} \mathrm{E}$ \\
\hline 5 & $140^{\circ} 00^{\prime} \mathrm{E}$ & $160^{\circ} 00^{\prime} \mathrm{E}$ \\
\hline 6 & $160^{\circ} 00^{\prime} \mathrm{E}$ & $180^{\circ} 00^{\prime} \mathrm{E}$ \\
\hline 7 (Chukchee Sea) & $180^{\circ} 00^{\prime} \mathrm{E}$ & $168^{\circ} 58^{\prime} 37^{\prime \prime} \mathrm{W}$ \\
\hline
\end{tabular}

The ice conditions in Arctic during the summer season are not very heavy. Captains with arctic experience say that the cargo ship of the Ice 3 class barely needs the icebreaker convoying for more than three zones in the summer season. Ships of Arc4 or Arc5 classes may go without convoying during the summer season because floating ice of 0.6 meter thick is rare at this time in normal seaways in the Arctic.
TABLE V. ICE CONDITIONS FOR SHIPS OF ICE CLASSES

\begin{tabular}{|l|l|}
\hline \multicolumn{1}{|c|}{$\begin{array}{c}\text { RMRS } \\
\mathbf{2 0 0 8}\end{array}$} & \multicolumn{1}{|c|}{ Class Definition } \\
\hline Ice 1 & $\begin{array}{l}\text { non-escorted in shallow open floating ice conditions, or } \\
\text { icebreaker escorted in ice channel for ice up to 0.4 meter thick }\end{array}$ \\
\hline Ice 2 & $\begin{array}{l}\text { non-escorted in shallow open floating ice conditions, or } \\
\text { icebreaker escorted in ice channel for ice up to 0.55 meter thick }\end{array}$ \\
\hline Ice 3 & $\begin{array}{l}\text { non-escorted in shallow open floating ice conditions, or } \\
\text { icebreaker escorted in ice channel for ice up to 0.7 meter thick }\end{array}$ \\
\hline Arc 4 & $\begin{array}{l}\text { non-escorted in open floating ice conditions up to 0.6 meter thick, } \\
\text { or icebreaker escorted in ice channel for ice up to } 1 \text { meter thick }\end{array}$ \\
\hline Arc 5 & $\begin{array}{l}\text { non-escorted in open floating ice conditions up to 0.8 meter thick, } \\
\text { or icebreaker escorted in ice channel for ice up to 1.2 meter thick }\end{array}$ \\
\hline $\begin{array}{l}\text { Arc } 6 \\
\text { Arc } 9\end{array}$ & $\begin{array}{l}\text { non-escorted in open floating ice conditions over 1 meter thick, } \\
\text { or icebreaker escorted in ice channel for ice over 1.2 meter thick }\end{array}$ \\
\hline
\end{tabular}

TABLE VI. CORRESPONDENCE BETWEEN RMRS ICE CLASS AND OTHER CLASSIFICATIONS

\begin{tabular}{|l|l|l|l|l|}
\hline RMRS 2008 & \multicolumn{1}{|c|}{ BIC } & \multicolumn{1}{|c|}{ DNVC } & LRIC & IACS-PC \\
\hline Ice 1 & Category II & ICE-C & $1 \mathrm{D}$ & - \\
\hline Ice 2 & IC & ICE-1C & $1 \mathrm{C}$ & - \\
\hline Ice 3 & IB & ICE-1B & $1 \mathrm{~B}$ & - \\
\hline Arc 4 & IA & ICE-1A & $1 \mathrm{~A}$ & PC7 \\
\hline Arc 5 & IA Super & ICE-1A* & $1 \mathrm{AS}$ & PC6 \\
\hline Arc 6 - Arc 9 & - & ICE-10, ICE-15 & - & PC5-PC1 \\
\hline
\end{tabular}

Finally, let us consider the calculation of the total cost of shipping through the Northern Sea Route per twenty-foot unit. For example, the ship base Vladivostok is a container ship belonging to the Far Eastern Shipping Company. The parameters of the ship base are presented in Table VII.

TABLE VII. PARAMETERS OF CONTAINER SHIP VLADIVOSTOK

\begin{tabular}{|l|l|l|}
\hline \multicolumn{1}{|c|}{ Parameter } & Unit & Value \\
\hline Year of Construction & & 1998 \\
\hline Classification & & RMRS \\
\hline Ice Class & Arc 4 \\
\hline Length & $\mathrm{m}$ & 184.1 \\
\hline Width & $\mathrm{m}$ & 25.3 \\
\hline Hull Height & $\mathrm{m}$ & 13.5 \\
\hline Loaded Draft & $\mathrm{m}$ & 9.89 \\
\hline Deadweight tonnage & ton & 23407 \\
\hline Gross Registerd Tonnage & r.ton & 16575 \\
\hline Maximal Speed & knot & 18 \\
\hline $\begin{array}{l}\text { Displacement, in TEU } \\
\text { Displacement, in homogenous TEU } \\
\text { loaded by 14,4 tons each }\end{array}$ & pcs & 1748 \\
\hline
\end{tabular}

Let us assume that the ship is in full freight and carries 1,087 twenty-foot units loaded by 14.4 tons of homogenous commodity each. The ship has the Arc 4 class, but let us assume that the icebreaker convoying through three zones in the bad case of ice conditions (Table II). The total cost of icebreaker convoying amounts to RUB 500,46*16575 ton $=$ 
RUB 8.3 million, or USD 151 thousand per ship voyage through the Northern Sea Route (RUB/USD exchange rate 55/1, approx. effective in 2017). The final cost of icebreaker convoying per twenty-foot unit is less than USD 140.

The roughly estimated cost of transportation of one twenty-feet unit through the North Sea Route is composed of the approximated cost of transportation, or not more than USD800, and the cost of icebreaker convoying that may reach USD140, or may be zero. The upper expectative cost per unit is USD940 comparing to USD1500 for the common way through the Suez Channel.

\section{CONCEPT OF LOGISTICS BURDEN FOR COST-TIME ALIGNING IN LOGISTICS NETWORK}

A person designing the logistics network generally faces the important logistics issue, i.e. the two incomparable parameters in the logistics chain are the time and the cost. The optimal route must be optimal in cost and in time, but the situation when one route is better in cost and the second one is better in time is rather frequent.

The main idea of aligning time and cost lies in the involvement of the concept of logistics burden based on the time value of money. The commodity in transit may be considered as a frozen capital. Actually, there may be two possible owners of a frozen capital. The commodity may be paid after a buyer receives it; in this case, the frozen capital belongs to the seller. Otherwise, the commodity may be paid in advance, and in this case, the frozen capital belongs to the buyer. All the same, the delay in logistics chain causes the financial loss of the owner equivalent to the lost interest for the period of shipping.

The aligning of the cost and time in logistics network may be achieved by adding the lost interest to the cost of the commodity transportation. The lost interest appears as the result of temporary freezing of the funds equal in the amount to the value of commodity for the period of time equal to the shipping time. The lost interest may be calculated as follows:

$$
L I=\text { Value }^{*}\left((1+i)^{n}-1\right)
$$

where $L I$ is the lost interest, Value is the invoice value of commodity, $i$ is the daily interest rate, and $n$ is the number of days in transit.

The logistics burden may be calculated as follows:

$$
L B=T C+L I
$$

where $L B$ is the logistics burden of a route, $T C$ is transportation cost, and $L I$ is the lost interest.

The suggested approach is very sensitive to the interest rate. There are many ways to determine the suitable value of the interest rate, and one of them is based on the legislative rules. For example, in Russian Taxation Code, the nominal profitability is assigned directly and equal to $20 \%$ yearly. That yields the cumulative rate of $0.049964 \%$ daily in a non-leap year. Daily rate looks unessential, but in case of expensive commodity and slow shipping, it may deposit significantly.
The lost interest increases the cost of transportation and shows the evidence of the well-known logistics principle that the expensive goods need fast transportation. For example, Fig. 1 shows the connection between the lost interest, shipping time, and invoice value of commodity for the interest rate equal to $20 \%$ yearly.

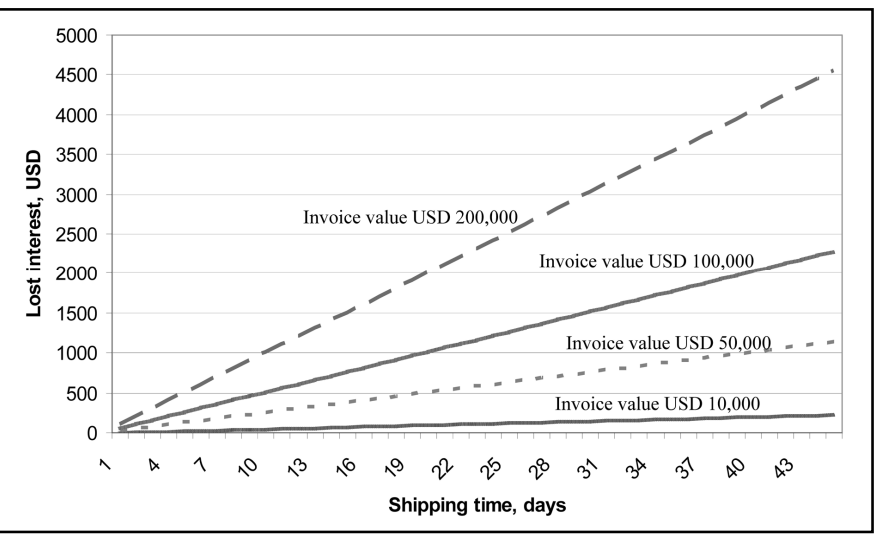

Fig. 1. Lost interest as a function of invoice value and shipping time, $i=20 \%$ per year

The total benefit of the commodity owner for the faster route is more than the direct economy on logistics burden. The faster return of the commodity value into the capital turnover must be considered as well. This effect decreases the logistics burden of the owner by the amount of the interest earned by the commodity value returned to the turnover for the period of time saved on the faster logistic route. To include this effect, authors suggest using the adjusted logistics burden for the comparison of logistics routes. There are longer and shorter routes in terms of time, and the adjusted logistics burden is calculated as follows:

$$
\begin{gathered}
A L B_{l}=L B_{l} \\
A L B_{s}=L B_{s}-\text { Value }^{*}\left((1+i)^{m}-1\right)
\end{gathered}
$$

where $A L B_{l}$ is the adjusted logistics burden of a longer route, $L B_{l}$ is the logistics burden of a longer route, $A L B_{s}$ is the adjusted logistics burden of a shorter route, $L B_{s}$ is the logistics burden of a shorter route, Value is a commodity value, $m$ is an advantage of a faster route in days.

The benefit of the owner for using the faster logistics route may be calculated as follows:

$$
\text { Benefit }=A L B_{s}-A L B_{l} \text {. }
$$

\section{A. Example}

The transportation cost of a twenty-foot unit is USD 1,500 and takes 35 days through the Suez Channel, or - USD 940 and 25 days through the Northern Sea Route. The unit contains the consumer electronics with the invoice value of USD 100,000. Let us calculate the owner benefit for the faster logistic route if the normal interest rate is $20 \%$ per year. 


\section{B. Solution}

1. Calculation of the daily rate:

$\mathrm{i}=\sqrt[365]{1+20 \%}-1=0.049964 \%$

2. Faster route takes 25 days, the longer one takes 35 days. The logistics burden is calculated as follows:

$$
\begin{aligned}
& L B_{l}=1,500+100,000 *\left((1+0.049964 \%)^{35}-1\right)=3,264 \\
& L B_{s}=940+100,000 *\left((1+0.049964 \%)^{25}-1\right)=2,197
\end{aligned}
$$

3. Advantage of the shorter route is $35-25=10$ days. The adjusted logistics burden is calculated as follows:

$$
\begin{aligned}
& A L B_{l}=3,264 \\
& A L B_{s}=2,197-100,000 *\left((1+0.049964 \%)^{10}-1\right)=1,696
\end{aligned}
$$

4. Owners benefit for the faster logistics route is:

$$
\text { Benefit }=3,264-1,696=1,568
$$

The total benefit of the owner reaches USD 1,568 if the owner decides to utilize the route that takes less time for shipping.

\section{CONCLUSION}

The development of the Northern Sea Route is usually considered as the Russian solo project. However, there are other parties who are interested in the implementation of this complex project. For example, China is interested in proportional development of their own territory. To achieve it, China needs to overwhelm the logistics restrictions for North Eastern provinces.

There is the third interested party too. Governments of the European Union understand that they are dependent on the Asian industrial core, which is demonstrated by their numerous initiatives on protection of their intellectual property. At present, the Asian industrial core agrees with the necessity of protectionism. However, the growth of transportation costs may trigger the segregation between the states of the European Union and Asia. If the countries of the Asian industrial core neglect the obligations on intellectual property protection, the slow but steady degradation of economies of the European Union may become a reality.

Therefore, states of the European Union may step in the megaproject of the Northern Sea Route as the important strategic ally in the development of the transport system of Russia and thereafter, one of beneficiaries of project advantages.

\section{References}

[1] Wang Guohong, "Prospects of Russian-Chinese cooperation in the labor migration field," Tomsk State University Journal, 2017, 416, pp. 61-68.

[2] Qu Wei, Wang Ai Xin, Da Zhi Gang, "Heilongjiang blue book: Heilongjiang economic development report (2015)," Social Sciences Academic Press, 2015.
[3] Maria L. Gorbunova, Igor D. Komarov, "A hybrid mechanism of multilateral economic cooperation as a new form of foreign policy of China," International Organization Research Journal (Higher School of Economics), Vol. 11, n.3, pp. 82-98, 2016.

[4] Igor A. Makarov, Anna K. Sokolova, "The Eurasian Economic Union and the Silk Road economic belt: opportunities for Russia," International Organization Research Journal (Higher School of Economics), Vol. 11, n.2, pp. 40-57, 2016.

[5] Anatoly A. Lugovets, Andrey I. Fisenko, "Economic interests transformation and perspectives of the development of Far East seaports," Marine Intellectual Technologies, n. 3(33), Vol.1, pp. 360366, 2016.

[6] Vladimir A. Lazarev, Maxim E. Krivelevich, "Integration of transportation spatios of Russia and Asia Pacific basing on Primorsky region," Modern Problems of Science and Education, Vol. 6, p. 419, 2013.

[7] Mikhail A. Ivanenko, "Realization of transit capacity of the Russian Federation on the basis of development of the international transport corridors", Vestnik Universiteta (State University of Management), Vol.4, pp. 120-124, 2017.

[8] Vasily S. Yurchuk, "Specific features of a legal regime of the Arctic," XI Int. Sci. Conf. Modern Problems of Utilization of Potential of Offshore an Near Shores Zones, Moscow University n.a. S.U.Vitte, pp. 446-452, 2015.

[9] Valery A. Tsvetkov, Kobilzhon Kh. Zoidov, Alexey A. Medkov, "Problems of economic security in Russian transportation and intermediate carrier infrastructure," Economics of Region (Institute of Economics, Ural Branch of Russian Academy of Science), Vol.1, pp. 100-109, 2012.

[10] "New icebreaker for China Army", available at http://military.china.com.cn/2016-01/04/content_37448983.htm

[11] "World Development Report 2009", Chapter 6: Transport Costs and Specialization, p. 172.

[12] "The North and the Arctic in the new global development paradigm: challenges, trends, prospects. Scientific-analytical report," Eds. V.S.Selin, T.P. Skufina, E.P. Bashmakova, E.E. Toropushina, Apatity, Kolsk Science Center of Russian Academy of Science, pp. 209-219, 2016.

[13] "On introduction of tariffs for icebreaker service on the ways of North Sea Route," Federal Tariff Service Order d.d. Jule 26, 2005, n.322-t.

[14] "On introduction of tariffs for icebreaker service on the ways of North Sea Route,” Federal Tariff Service Order d.d. June 7, n.122-t/1, 2011

[15] "On introduction of tariffs for icebreaker service of Federal Enterprise ATOMFLOT in the aquatorium of North Sea Route," Federal Tariff Service Order d.d. March 4, n.45-t/1, 2014.

[16] "Register book of vessels," Russian Maritime Register of Shipping, 2015.

[17] "The structural design and engine output required of ships for navigation in ice "Finnish-Swedish Ice Class Rules," Finnish Maritime Administration, Swedish Maritime Administration, Ver.1, Dec 20, 2005.

[18] "Finnish ice classes equivalent to class notations of recognized classification societies and documentation required for the determination of the ice classes of ships," Transport Safety Agency TRAFI/31299/03.04.01.00/2010.

[19] "Ships for navigation in ice," rules for classification of Det Norske Veritas AS, July 2011

[20] Robert Tustin, "Arctic tankers: structural dimensioning considerations," TSCF 2013 Shipbuilders Meeting, 24th October 2013, available at http://www.tscforum.org/TSCF/bfiles/2013/Paper 5.2 - (only PPT)Arctic Tankers structural dimensioning considerations.pdf. 